\title{
The Role of a Pastor's Spouse in Church Growth: A Case Study of the Seventh Day Adventist Midlands Conference
}

\begin{abstract}
Linda Sibanda*
Adventist University of Africa, Theological Seminary, Zambia

*Corresponding Author: Linda Sibanda, Adventist University of Africa, Theological Seminary, Zambia

Abstract: The purpose of this study was to examine whether a pastor's wife plays a significant role on church growth in Midlands Conference in Zambia's Seventh Day Adventist (SDA) Church. The objectives of the study included to find out the views that pastors have on their wives' involvement in ministry, also to get the views of shepherdesses on their readiness to serve with their wives and assess the qualification of the pastors and shepherdesses in Midland Conference. The population was made up of 34 pastors and 34 shepherdesses in the Midlands Conference for the year 2015. In order to provide precise results, the researchers adopted both qualitative and quantitative methods and data was collected using questionnaires with open ended questions. Data was gathered using questionnaires prepared by the researcher. The findings were analysed using SPSS 23.0 and thematically. The study found that most of the Pastors in Midland Conference agreed that shepherdesses played a big role in their ministry and were very ready to serve with them. The study also revealed that the majority of the pastors' wives were willing to support the work of ministry of their husbands. In addition, the study showed that most shepherdesses also were professionally trained and this would be added advantage as they shall serve with understanding. In view of the results obtained from this study, it was recommended that the Midlands Conference shepherdesses should prepare and organize ongoing educational programs to equip and empower the shepherdesses so as to enable them to perform efficiently in team ministry with their husbands. And that in order for the pastor and spouse to improve the ministry, the two should always work together.
\end{abstract}

Keywords: Role, Church growth, Shepherdesses, Midlands Conference

\section{INTRODUCTION}

The family impacts on the growth of every member and plays an important role in the functional operation of a social system. Therefore, a families' function is restricted by the family itself and relies on social expectations (Dai \& Wang, 2015). Pastoring is among the few most respected and trusted professions. Therefore, members of society trust pastors with their problems and other traumatic experiences. These engagements with congregants usually are not restricted by time boundaries, as congregants expect the pastor to be available at all times. These commitments usually result in limited time between him and the family (Gauger and Christie, 2013). Therefore, one can not underestimate the role of the shepherdess or the pastors' wife as she automatically fills in the large void left by the pastor at home as he attends to his congregants. The wives of pastors seem to have additional roles other than their normal roles as women.

The general saying is true that besides every successful man is a woman. If the woman supports the ministry that support has a good impact. If the woman does not support the ministry, it is accompanied by a negative impact. White (2007) contended that apastor's success or failure depends very much on the spouse. The good that the pastor does is pulled down by the negative acts of the spouse. So as the pastortries to minister effectively the spouse can pull it down because of her negative attitude if her role is not recognized by the church organisation.

The wife to the pastor plays a lot roles in simple ways what the husband may forget to do of crucial matter, the wife can always remind him if her role is recognized in ministry. Having known the strength and weakness of each other they can be able to strengthen one another where the other is weak so much so that the weakness may be covered up. White (2005) affirms that the husband and wife can so blend in labor that the wife shall be the complement of the husband. This will help to bring out only the strengths. 
There are also some exceptional situations that need the ministry of a woman especially among sisters. White (2007) added that if a minister's wife possesses the spirit of self-sacrifice and has love for souls, his wife can with him do almost an equal of good. The spouse can reach some, especially among their own sex, whom the pastor cannot. There are certain experiences that can be hard to share with a man but with women. Fellow women easily open up and share their problems. The Pastor`s wife is therefore able to minister beyond the husband in such cases. She can encourage, counsel and pray with them.

If one takes history into account, a global trend is found were most pastors did not take into account the roles and the call of their spouses when they decided to become pastors. Their desire to work for the Lord and spread the gospel was of utmost importance and everyone in the family had to adjust to this change (White, 2015). In extreme cases, many other others moved out of town without involving their spouse and the rest of their family, some while in the same town spent less time at home. Their commitment to the work of God became their most important commitment. Even today one can observe that the pastor and spouse is globally in an environment where marriage and ministry do not fit together (White, 2015). It brings in the complexity of who is called between the couple and what the other is to do. While, the other is still trying to fit in, the called is already extremely devoted to their call that this leaves the uncalled spouse with no or very limited options on how to respond to the new situation and the role they need to play.

To discuss the Seventh Day Adventist perspective on Team Ministry, the researcher has opted to make reference of Ellen G. Whites counsels on the matter. Both men and women are needed in the ministry. The women can be instruments of righteousness, rendering holy service. White (2005) acknowledged that women are also needed in the work for salvation of souls. It has been noted that the church is lacking in deeds of sympathy and care in the ministry to the needy, oppressed and the suffering. These are areas that the pastors' wives can consider in their team ministries with their spouses. They can be able to reach out to these marginalized people and minister to them effectively taking care of both their spiritual and physical needs.

\section{Statement of the Problem}

Husbands and wives experience different kinds of challenges and these are caused by the perspective one has of their role in Ministry. The call of the pastor and his wife have different dynamics. One of them is on whether they got married when they were called to ministry, before or after they got married (Wimber and Kelvin, 2007). This later results in one probably having another vocation yet having to still try and participate in the activities of their spouse at the local church. This further deepens when one takes into account the expectations of the local church on the spouse. It has since been realised that the pastors' wife experiences higher stress levels than ordinary wives in the congregation as their roles are not recognised. This is as a result of financial and family matters, loneliness while there is high expectation and demands that is expected from the pastor's wives (Nandasaba, 2011).

\section{PURPOSE OF THE STUdy}

The purpose of this study was investigate the roles that pastor's wives can play and put into practice an initiative that would promote pastoral and the wife to work together in ministry in Midlands Conference.

\section{STUdy OBJeCTIVES}

a) To find out the challenges affecting that pastors face working in ministry without the Shepherdesses in the Midlands Zambia Conference.

b) To get the views from both pastors and shepherdesses on how both desire the involvement of the wives in ministry.

c) To assess the professional qualification of the shepherdesses and how that can help in ministry for their husbands.

\section{The Role OF A Wife in MARRIAGE}

Team work in marriage begins at creation when God created Adam and later on Eve who was his team mate. The Bible says that, “.... but for Adam there was not found any help mate for him”, 
(Genesis 1:20). God made Adam to sleep a deep sleep as he made a woman. When God awoke Adam from the sleep he exclaimed as he saw somebody fit to be his team mate. He said, "This is now bone of my bone, and flesh of my flesh........" (Genesis 2:23). The woman was created to be a helper to play a role in the family. Peterson (2013) stated that the word translated as helper comes from a root that is used through scripture in the sense of providing strength and rescue. From this statement we see that a wife can provide strength and even rescue the pastor from stress and other accusations in ministry. Eve was to be a valuable team mate. A woman therefore is the perfect complement to man through marriage. Catherine (2013) agrees with Galen Peterson in that God brings together a man and a woman in marriage so that together they can help one another in difficult times, and to grow and function in a way that they cannot do separately. In this way marriage was to be complementary and necessary. So the relationship between a man and a woman is designed to be harmonious by nature and diverse by function.

Team-ship in marriage is closer than the bond between parent and child. In fact, the husband and wife were to leave and cleave to one another, "Therefore shall a man leave his father and mother and shall cleave unto his wife and the two shall be one flesh". (Genesis 2:24). This signifies composite unity of two people united as one in marriage. In other words, key allegiance belongs to each other above even the close bond of parent and child. So in essence the couple is to love each other first before everything else except of God.

There is interdependence on each other between husband and wife. Paul says that, "Nevertheless neither is the man without the woman, neither the woman without the man in the Lord." (1 Corinthians 11:11). Paul goes on further to say that, "For the woman is of man, even so is the man also by the woman, but all things of God". (1 Corinthians 11:12). The team-work in marriage requires compatibility, companionship, nearness, personal involvement and cooperation. This means you are together for life, in good times and bad times sharing joys and sorrows, burdens in sickness or health, hardship or success. There should be no pulling against each other but pulling with each other in the same direction. Teamwork in marriage is a case of me and you against the world. Unity is an important aspect of team work in marriage between husband and wife. There should be unity of thought, affection, purpose and spirit. The fact that the couple is one flesh is the more reason for them to be united. The couple has a mutual duty to God which is nurturing God fearing children. For that to be attained the couple should identify the principles of headship and submission. They should also learn to communicate well and to be united just as the unity of the Godhead.

\section{THE Role OF A WifE IN Biblical COUPLES}

The foundation of the role of the wives in ministry is found in the Bible. There are many biblical couples who laid a foundation for team ministry. Among them the following will be considered, Abraham and Sarah and Moses and Ziporah in the Old Testament. In the New Testament ministering couples such as Zachariah and Elizabeth and Aquila and Priscilla will be investigated.

\section{a) Abraham and Sarah}

The story of Abraham and Sarah begins in the Ur of the Chaldeans. "A thriving metropolis near the ancient coastline of the Persian Gulf (Strauss, 2019). God spoke to Abraham and said, "Get thee out of thy country and from thy kindred, and from thy father's house unto a land that 1 will show thee." (Genesis 12:1). Abraham obeyed God. He started off with his nephew Lot, and his wife Sarah. Sara's role to support Abraham originates clearly from the beginning Sarah does not object to the idea of going to a place they both did not know. It seems as though Sarah must have decided as her mission in life to do the task of helping her husband fulfill God's purpose for him. Sarah called his husband "Lord" (1Peter 3:6). This was Sarah's way of expressing her submissiveness and even obedience. The element of faith also creeps in. Submission for a wife is the belief that God is working through the husband to do what is best for her. Here we see the role of submission to the husband.

In addition, Sara's role is demonstrated in entertaining the guests from heaven who were on their way to destroy Sodom and Gomorrah (Genesis 18:6). It is recorded in the bible that Abraham ran into the tent to Sarah to let her know about the guests and to give some instructions for food arrangements. He said to Sarah, "Make ready quickly three measures of fine meal, knead it, and make cakes upon the heath" (Genesis 18:6). The fact that Abraham told Sarah to make ready quickly the flour might suggest that it could have been sifted from the bran and could have been in the house ready for use. 
Maybe it needed to be mixed and kneaded and made into cakes. It should also be known that Abraham ordered three measures of flour. This means he was willing to have and to make a plentiful entertainment for them. He ordered Sarah to do that, she did not object. Sarah whole-heartedly engaged in the activity of food preparation.

Sarah also teamed up with her husband against approaching danger as they neared Egypt. Abraham said to Sarah, "Say 1 pray thee, thou art my sister that it may be well with me for thy sake" (Genesis 12:13). Abraham thought the Egyptians would murder him and take his wife. He also thought he would be honored if they thought that he is the brother. That is exactly what happened, he was given animals and servants for her sake (Genesis 12:16). Sarah was Abraham's half-sister but she was also his wife. "Such marriages were not unusual in that day." However, the truth still remains, she was only his half-sister but also his wife. Abraham and Sarah told Pharaoh a half-truth tantamount to a lie. One would have expected Sarah's obedience to God to surpass the suggestions of her husband. When obedience compromises the word of God a wife has no obligation to obey her husband (Acts5:29).

\section{b) Moses and Zipporah}

This team met at a well just like Jacob and Rachel (Genesis 29:10). Moses and Zipporah were blessed with two sons Geshom and Eliezer (Genesis 18:2-3) whom they were to bring up together as a couple. The Bible indicates that, "And Moses took his wife and his sons and set them upon an ass and here turned to the land of Egypt..." (Genesis 4:20). It is important to note that Zipporah did not object to leaving her family going with Moses to Egypt. She accepted to go with him and that was a good spirit of team - ship.

On their way to Egypt, Zipporah performed a bold act concerning circumcision. It is recorded in the bible that, "And it came to pass by the way in the inn, that the Lord met him, and sought to kill him." (Exodus 4:24). The context reveals that the, "One almost killed by God was Moses. Zipporah took a sharp stone and cut off his foreskin of her son and cast it at his feet..." (Exodus 4:25).Zipporah knew what to do and she did it. It comes out clear that what Zipporah did indeed stopped God's hand against Moses and so she saved his life. God's requirement was circumcision and she did it, in that process practicing team ministry. She performed a very important Act in Jewish system. In Genesis 17:11 circumcision was the covenant sign given by God to Abraham and his descendants. Never the less the point is that she herself performed the act of circumcising her child thus fulfilling God's requirements and practicing team ministry with her husband. It could be expected of Moses' son to carry the covenant sign. Ignoring that command could be tantamount to open disobedience. However, such an omission could not be tolerated in Moses as God's chosen and respected servant. Hence, the scene of Exodus 4:24 where Zipporah saved the situation.

\section{c) Zechariah and Elizabeth}

Zechariah was a priest during the days of Herod, the king of Judea. His wife was Elizabeth. The bible says that, ".... they were both righteous before God, walking the commandments and ordinances of the Lord blameless," (Luke 1:6). This couple had worked together in marriage but had no child. They had even grown old but the prayer for a child had not been answered. It seemed as if God had delayed. God's delay was not his denial. In his time he made things beautiful for them. In this case the longer it took for the promise to be fulfilled, the greater the impact.

It should be noted that Elizabeth worked with Zechariah as a team despite that there was no child in the family (Fuller, 2010). This team however depended upon the Lord for the blessings of a child. The answer to the prayer came when Zechariah was ministering at the temple. The angel Gabriel came to Zechariah and said, "Fear not Zecharius for thy prayer is heard and thy wife Elizabeth shall bear thee a son and thou shall call his name, John," (Luke 1:13). The promise was fulfilled. Elizabeth and Zechariah again demonstrated their team ministry eight days later when they took the child to be circumcised.

Elizabeth supported Zechariah in ministry even when it called for a contradiction with their culture. Elizabeth's extended family decided that the baby would be given Zechariah the father's name, but Elizabeth contradicted them. She told them that her son's name was to be John, (Luke 1:60). It should be noted that there was no family precedent for the name, even though the family argued Elizabeth stood her ground. Exasperated the family members turned to Zechariah for support, who indicated through writing that his name is John, (Luke 1:63). This couple obeyed the command of God even against the words of their family members. 


\section{d) Priscilla and Aquila}

Priscilla and Aquila practiced worked as a team where Priscilla supported Aquila throughout in church growth. In fact in the case of this couple, it doesn't show that Aquila was a pastor but the two worked together in ministry. They worked together leading a church in their home, (Romans 16:3-5). This team was a husband and wife team who lived together, worked together and ministered together. Aquila and Priscilla is a model of team work in the New Testament (Bresee, 2007). They were involved in forming, nurturing and leading house churches. These two were fellow workers in the ministry of Jesus Christ with Paul. In Romans 16:3 Paul refers to them as, "my fellow workers in Christ Jesus." Paul left these fellow workers in Christ Jesus in the city of Ephesus.

It is very interesting and of great significance that their names are always mentioned together in scripture as if they were inseparable. This signifies the role that Priscilla played in ministry. They were a good model of a beautiful team ministry based on common submission and respect. It seems that Priscilla chose to follow her sense of calling instead of limiting herself to home making. There are times that financial reality dictates that husband and wife put their efforts together to do God's work without splitting the family and resources. In this case, Priscilla and Aquila worked hand in hand not just to earn a living, but also to spread the gospel of Jesus Christ.

Priscilla and Aquila practiced team ministry in teaching. This is revealed in an event that took place in Ephesus. It is recorded in scripture that a Jew named Apollos born at Alexandria, an eloquent man and mighty in scriptures came to Ephesus, (Acts 18:24). Apollos was instructed in the way of the Lord, he taught diligently the way of the Lord but his knowledge was limited to the baptism of John, (Acts 18:25). He spoke boldly in the synagogue. When Priscilla and Aquila heard him, they sought to teach him the way of the Lord more accurately (Acts 18:26).

Priscilla and Aquila seem to have been ministering laborers with pastor's hearts. They would not go and reach to lost souls for Christ only to be left in someone else's pastoral care but where ever they went they would establish a church in their home. They must have believed in the community. To them the gospel was not an individual matter, it also had a social dimension, and Priscilla and Aquila were a husband and wife team concerned with building Christian communities among believers (Schussler, 2007).

It is therefore very important to recognize the role of the shepherdess in mi ministry. This is a call for team ministry where the spouse willingly offers her service together with the husband in God's service. In other words, the pastor's wife does everything she can do to enhance the ministry and combines her efforts with the effort of the husband. The spouse of the pastor should enter heartily into his labors seeking every opportunity to unite her interests and labor with her husband. It becomes one team ministry. It is important to recognize that God calls the Pastor and Spouse to work together as a team. It definitely will not work if the spouse is not in support of the ministry. God calls both men and women to his ministry.

\section{SPECial ROLES OF A SHEPHERdeSS}

It is pointless to say that team ministry begins right from the home of the pastor. The shepherdess has a primary role or responsibility to be a teammate to their husband. She ministers to the needs of the husband and children especially when they are young. She has to make her home a small heaven on earth for the husband and children. It has to be a refuge or place of safety so the pastor's wife can make an effort to create a refuge for her family to retreat to and a peaceful place that is secure. It should be home where not only strangers are welcome but where children and the pastor finds rest, peace and tranquility. It should therefore be realized that the team ministry of taking care of the pastor and children is also a special calling that should not be deserted by shepherdess.

Biblically the shepherdess has a special calling to respect their husbands (Ephesians 5:33). They are to be helpers (Genesis 2:18) and to care and nurture their children (Titus 2:45). As a team mate the shepherdess might stay awake with him as she helps in sermon preparation especially if she is also trained in ministry. Even without ministry training she can help even in sermon typing and capturing grammatical errors. She should be there to share his pressures and even disappointments as well as to suffer defeat together. This goes beyond even in facing criticism and negative comments about herself, her husband and even children. It is a very important role for the shepherdess to honor and support her husband. 
A shepherdess often provides an ear for the pastor to vent, brainstorm and discuss church progress and even goals of the church. She should be steadfast and support the vision that God has given to them. Many times she may have to be a nurse, healing emotional wounds that they go through. She should be a counselor to help her husband to work out difficulties that may come in the ministry. Above it all she is also a lover and protector to shield him from harm and danger and to provide the loving care that is needed in ministry. Some pastors may not have close friends to share with their problems so a shepherdess should provide that companionship that encourages him to continue even when tempted to give up.

The shepherdess may also team up with the pastor in counseling if God has given her that gift or if she is a trained counselor. She can invest in the lives of others through encouragement, guidance and listening to their problems without being judgmental. The church can benefit from the counsel of their mother. She can make a significance difference in every part of her world. In other words, the shepherdess can contribute much in ministry. When she teams up with her husband, she can also show a faithful love for the members they are serving and be truly everyone's mother in the congregation.

Another special area of team ministry for the shepherdess is visitation. She can accompany the pastor and minister with him during visitations. Even when she is alone or with children she can make visitations and pray with and for God's people she is still part of the team. It is through these visitations that God's people are encouraged to keep the faith and be faithful to God despite any challenges in their life. In the same vein her teamwork with her husband will help so that the needs of female congregants are met. Some women will find it easier to approach the shepherdess than the pastor. So the role of the shepherdess really makes a difference.

During funerals when church members lose their beloved, the shepherdess should team up with the minister to comfort their members. It is important to nurture them as they go through the process of bereavement. As a pastor's wife the shepherdess has been afforded the opportunity through choice, agreement and marriage to be part of church ministry together with her husband and is therefore responsible for God's children.

\section{Educational LeVEl OF SHEPHERDESS}

In focusing on a pastor's wife and team work it is important to realize the role of education. Education will help the pastor's wife to be confident as she teams up with her husband. It is important to note that it may be hard for a pastor's wife to be equipped fully for ministry, nevertheless general assurance is helpful. However, it is important that a pastor's wife engages in formal or informal studies to widen her horizon of knowledge. This will also build her sense of confidence.

Role modeling is part of a pastor's wife and team work. Some members both in the church and outside look upon the pastor's wife as a role model. If she misses the mark the ministry is affected, it is pulled down together with her husband. Dobson (2004) indicates that wives of any kind of ministers are observed and therefore are role models for others. This reveals the importance of the role God has given the pastor's wives together with their husbands. It is possible that one may be looking upon the pastor himself as a role model. This calls for the emulation of the life of Christ by both the pastor and the spouse so that those who are following them may also follow Jesus Christ.

The importance of identity awareness has a great impact on a pastor's wife and team ministry. The pastor's wife should know the reason for her existence, her purpose and her identity in Christ. With this knowledge, a pastor's wife develops confidence which helps her fulfill her calling and in the same manner helps her to support her husband as a wife and teammate. So the level of education for the pastors' wives play a major role in this.

\section{Methodology}

Qualitative and quantitative methods were used in this research. The qualitative approach takes into consideration the experiences of the people from their own perspectives. This method also brings to the surface what the pastors and shepherdesses feel about their role in ministry. Their knowledge and opinions are also brought out. The information given by the respondents is shown through tables. In order to assist in the analysis, the percentages are also given. 
The questionnaires used were the closed ended and open ended questions. These were given out so that the pastors and shepherdesses would be able to share their views in a better way. The advantage of open ended questions is that they enable the respondents to share their deeper thoughts from the bottom of their hearts, the questionnaire for the pastors comprised of 8 questions while that for shepherdesses had 9 questions. The questions sourced the demographic information of the respondents and the views about the role of the shepherdess and their qualification in ministry. Personal observation was used by the researcher so as to get more data. Being a shepherdess leader for Midlands Conference, Lusaka Zone, the researcher was able to observe what was happening among pastors and shepherdesses regarding team ministry. Data was also obtained from the statistical reports and some documents from the conference secretary.

The researcher requested the Midlands conference to grant her the permission to carry out the research. In seeking the permission, the researcher also received the leadership support. The permission was granted to the researcher. Before data collection, one meeting was called where both pastors and shepherdesses came at City Education Church. 30 out of 34 pastors and their wives attended this session which represented $88.2 \%$. This meeting was meant to introduce the study to the pastors and their spouses. During this meeting, the objectives as well as the justification of the study was shared. All the pastors and their spouses present agreed to participate in the study. The researcher assured all those present of confidentiality and the names of the respondents were not going to be indicated in the questionnaires. The couples present were requested to give true answers to the questions given. They were given the rule to answer the questionnaires individually so that each would respond to the questions freely. The respondents were given the questionnaires and they were to answer them promptly and return them at the end of the meeting. This was done to make sure that all the respondents brought back their questionnaires. Interviews were also done to get in - depth information from 5 shepherdess and 5 pastors. Later, the quantitative data was analysed using SPSS 23.0 version and some descriptive findings were recorded and the qualitative data was thematically analysed were themes emerged.

\section{FINDINGS AND DISCUSSION}

\section{a) Demographic Profile of the Shepherdesses}

The researcher came up with a demographic profile which required the respondents to identify their gender, age, status, marriage, level of education, their profession and years of experience as a pastor or a shepherdess. The results of the demographic profile of the shepherdesses indicated that there were two shepherdesses that were elderly. They are also experienced in ministry and with virtue of their age full of wisdom too. They will be of great benefit in terms of guidance to the young ones. The majority of the shepherdesses are between 41-60 years. This group has also mature people who can work with the two elderly shepherdesses to guide and counsel the young and help them learn to team up well with their husbands. The young shepherdesses between 30-40 years and also those below 30 years can be trained in their roles in ministry and also receive guidance from those who have served longer. They have more years of service awaiting them and so, if trained properly, the church will benefit from their team ministry for many years. The other elderly shepherdesses will also, if empowered with skills for team ministry, benefit the churches through team ministry with their husbands.

The table of educational level of the shepherdesses shows that there is no one who ended with primary level, they are all above the primary level. Five shepherdesses have completed secondary school and are not employed while 15 have tertiary education. Eight shepherdesses have first degree. Two shepherdesses have masters' degree. The results reveal that the majority of the shepherdesses have been to school. They have reached at least the level of secondary education, some have tertiary education. The fact that none of the shepherdesses ended at primary school is also an added advantage. It means that they can be easily trained and equipped for team ministry.

It was revealed in this study that the majority of the shepherdesses were professionals. They hold certificates and diplomas. Among them, the government workers were 15 while private workers were 10. Three are self-employed while two had already retired. It is observed that the shepherdesses were kept busy at their workplaces. As a result, most of them were free to do God's work during the weekend. 
The Role of a Pastor's Spouse in Church Growth: A Case Study of the Seventh Day Adventist Midlands Conference

This study revealed that 20 shepherdesses had spent five years and above as shepherdesses, six have been shepherdesses for four years while four have been shepherdesses for three years. 20 shepherdesses have experience in ministry while 10 are relatively young in ministry. The implication of this study is that the Midlands conference is blessed with many shepherdesses who are mature and will be powerful tools for team ministry. In addition to that, the young have many mentors in ministry.

Table1. Demographic profile of the Shepherdesses

\begin{tabular}{|l|l|l|}
\hline Description & Category & Frequency \\
\hline Age & Above 60 & 2 \\
\hline & $41-60$ & 15 \\
\hline & $30-40$ & 8 \\
\hline & Below 30 & 5 \\
\hline Marital status & Married & 30 \\
\hline Educational level & Primary & 0 \\
\hline & Secondary & 5 \\
\hline & Tertiary & 15 \\
\hline & $1^{\text {st }}$ degree & 8 \\
\hline & Masters & 2 \\
\hline Profession & Government workers & 15 \\
\hline & Private workers & 10 \\
\hline & Self employed & 3 \\
\hline Experience as a shepherdess & 1 year & 0 \\
\hline & 2 years & 0 \\
\hline & 3 years & 4 \\
\hline & 4 years & 6 \\
\hline & 5 years and above & 20 \\
\hline
\end{tabular}

Source: Fieldwork, 2020

\section{b) Challenges Faced by Pastors and Shepherdesses}

The findings as revealed by Table two below revealed that a good number (47\%) of the pastors experienced no challenges with their spouses whilst $27 \%$ of the pastors were of the view that they had limited women affair programmes, $9 \%$ felt that personality and opinion differed, $12 \%$ indicated that they encountered challenges when domestic pressures interfered with God's work and $6 \%$ felt that because their spouses were busy with their own work.

In a face to face interview on the challenges of how to work together as pastor and shepherdess one pastor explained that,

'For me madam, I don't have challenges with team work with my wife, I support her whenever she wants to do something and what note and she supports me too, though sometimes we have different opinions"' (Pastor 1)

Another Pastor said

"I can barely mention a challenge because I think I am working very well with my wife." (Pastor2)

Therefore, these findings imply that the majority of the pastor's do not encounter challenges with their spouses in regard to ministry work.

Table2. Challenges Faced by Pastors

\begin{tabular}{|l|l|l|}
\hline Challenges faced by pastors & Frequency & Percent \\
\hline Limited women affairs programmes & 8 & 27 \\
\hline No challenge & 14 & 47 \\
\hline Personality and opinion differ & 3 & 9 \\
\hline Domestic pressures interfere with God' s work & 3 & 12 \\
\hline Because their spouses are busy with her work & 2 & 6 \\
\hline Total & $\mathbf{3 0}$ & $\mathbf{1 0 0}$ \\
\hline
\end{tabular}

Source: Fieldwork data, 2020 
There is power in a pastor and spouse team. Even in terms of quantity the two can produce more. One would say that a team can produce more than the sum of the individual. It should be realized that an individual can do so little while more can be done by a pastor and spouse team. Indeed one obvious reason being that the husband and wife multiply energy. If two people work together more energy is put and hence more work. It should be realized that if one were to be overpowered two can still be able to defend themselves. The fact is that more work happens when the pastor and spouse work together to accomplish a goal.

It should also be noted that even in terms of quality two can be able to produce better quality than one person. Byler (2008) supports by saying that the quality is improved when people work together. It should also be noted that a pastor and spouse team can improve on each other's weaknesses. Where the other may be weak the other may be strong and so the two strike a better balance. When the shepherdess were asked during interview on working together with their spouse instead of secular employment, this is what one had to say;

I would have loved to team up, Being shepherdess requires visiting members, counselling, encouraging, sometimes employers cannot give you permission to attend to the funeral, doing other works affects team work affects time and so forth, now can't mainly because I am not full time in the ministry, but I am working in the circular (Shepherdess1).

\section{c) Areas Where Shepherdesses Could be Involved to Assist in the Ministry}

With regard to areas where Pastors thought Shepherdesses could be involved to assist in the Ministry, the findings as shown in Table 4 below revealed that the majority of respondents $51 \%$ were of the view that they should be involved in skills training and counseling, $18 \%$ indicated that they should be involved in issues of women and children, $27 \%$ felt that they should be involved in hospitality and singing and $6 \%$ indicated that they should be involved in teaching bible study. Teamwork may be recognized as the role of a pastor's wife. It should be noted that a pastor's wife gives a sounding board for her husband to learn, brainstorm and question his progress or even goals. She encourages and is steadfast to support the vision that God has given them. The support of a pastor's wife is very important. She provides companionship that encourages the pastor to continue with ministry even when he feels like giving up. The Pastor's wife should share the opinions and burdens. She will often keep her husband's long hours, shoulder the pressure, and share in the disappointments as well as pain in times of defeat. In her team ministry with her husband she might often analyze sermons, checking on grammatical errors and may have to face criticism and even negative comments. The pastor's wife in short ministers with her spouse. However, all the shepherdesses felt that they were doing enough in assisting the pastors in the ministry.

Table3. Areas where Shepherdesses could be involved to assist in the Ministry

\begin{tabular}{|l|l|l|}
\hline Areas where Shepherdesses should be involved & Frequency & Percent \\
\hline Teaching bible study & 2 & 6 \\
\hline Hospitality and singing & 9 & 27 \\
\hline Issues of women and children & 4 & 18 \\
\hline Skills Training and counseling & 15 & 51 \\
\hline Total & $\mathbf{3 0}$ & $\mathbf{1 0 0}$ \\
\hline
\end{tabular}

Source: Fieldwork, 2020

\section{d) Areas Shepherdesses thought they Could be Empowered to Assist in Ministry}

With regard to areas the shepherdess thought they can be empowered to assist in ministry as shown in Table 9 , the study revealed that $6 \%$ of the respondents were of the view that by educating people about the importance of the kingdom, $18 \%$ felt that by doing some community services, the majority of the respondents, $57 \%$ were of the view that by being involved in team work, $21 \%$ indicated that by attending seminars they can help in the ministry.

Therefore, it can be observed that many shepherdesses wanted to be involved in team ministry. They understood that team work can achieve tremendous result and thus promoting the kingdom of God here on earth. 
The Role of a Pastor's Spouse in Church Growth: A Case Study of the Seventh Day Adventist Midlands Conference

Table4. Areas the shepherdess can be empowered to assist in ministry

\begin{tabular}{|l|l|l|}
\hline Areas to be involved in & Frequency & Percent \\
\hline By educating people about the importance of the kingdom & 2 & 6 \\
\hline Doing some community services & 1 & 18 \\
\hline Involved in team work & 17 & 57 \\
\hline Seminars & 6 & 21 \\
\hline Total & $\mathbf{3 0}$ & $\mathbf{1 0 0}$ \\
\hline
\end{tabular}

Source: Fieldwork, 2020

\section{e) Pastors' Views on What Should be Done to Improve the Ministry}

With regard to what should be done to improve the ministry, pastors were asked to state their views (Table 5) below and the findings revealed that the majority $(61 \%)$ of the respondents were of the view that more funds should be allocated for team ministry not only pastors, $27 \%$ indicated that there should be a deliberate policy to empower shepherdesses and $12 \%$ felt that more training and seminars be provided.

Table5. Views on what should be done to improve the ministry

\begin{tabular}{|l|l|l|}
\hline Views & Frequency & Percent \\
\hline A deliberate policy to empower shepherdesses & 8 & 27 \\
\hline More funds should be allocated for team ministry not only pastors & 18 & 61 \\
\hline Provide more training and seminars & 4 & 12 \\
\hline Total & $\mathbf{3 0}$ & $\mathbf{1 0 0}$ \\
\hline
\end{tabular}

Source: The researcher, June, 201

Table6. Views on the Roles the Shepherdesses can do to Support the Ministry

\begin{tabular}{|l|l|l|}
\hline Views & Frequency & Percent \\
\hline Be involved in local church programmes with the pastor & 2 & 6 \\
\hline providing counseling especially on women's affairs and youths & 12 & 41 \\
\hline to be a supporting staff to the husband & 16 & 53 \\
\hline Total & $\mathbf{3 0}$ & $\mathbf{1 0 0}$ \\
\hline
\end{tabular}

Source: Fieldwork Data, 2020

\section{f) Responses on What Should Be Done to Improve Team Ministry}

Team ministry is very important in achieving the goal of the church and in trying to establish on what should be done to improve team ministry, the findings from the shepherdesses as shown in table 6 revealed that the majority $51 \%$ were of the view that Shepherdesses and Pastors should be working together, $21 \%$ felt that more seminars should be conducted, $15 \%$ indicated that more teaching should be conducted and another 15\% were of the view that Shepherdesses and pastors should be praying and encouraging each other.

\section{CONCLUSION}

Teamwork may be acknowledged as the role of a pastor's wife. It should be noted that a pastor's wife gives a sounding board for her husband to rent, brainstorm and question his progress or even goals. She encourages and is steadfast to support the vision that God has given them. The support of a pastor's wife is very important. She provides companionship that encourages the pastor to continue with ministry even when he feels like giving up.

The strongest testimony of a pastor's wife and team ministry is visible when people see the team together, enjoying, living life together and even ministering together. Lorna Dobson supports, "No single activity is more important than spending time with the word of God (Dobson, 2004). In addition being together also helps to keep the enemy far away. Both the pastor and the spouse are kept from becoming vulnerable to the enemy's attacks of sexual temptation. It should be noted that if you do not spend time together or you are not seen together, wrong signals are sent to people regarding your vulnerability. From the study, it has been shown that the pastor and spouse team lives to improve the ministry. The two working together work better than each given their individual effort. The pastor and spouse team should exist to accomplish the vision of ministry. The pastor and spouse team should not live to serve themselves but the God who has called them to ministry. Therefore, the pastor and spouse team should always work together. The salvation of souls should be cardinal in everything they do. Furthermore, the purpose of the pastor and spouse team is greater than the individual. 
The Role of a Pastor's Spouse in Church Growth: A Case Study of the Seventh Day Adventist Midlands Conference

\section{RECOMMENDATION}

From the findings the following recommendations have been drawn.

a. The pastors and shepherdess should always team up in the teaching of the gospel of Jesus Christ. It is important therefore to come up with the roles that shepherdesses can play. Shepherdesses should also develop skill for their spiritual growth and the growth of the church.

b. There is need to come up with a church policy to empower the shepherdesses in ministry and work with their spouses.

\section{REFERENCES}

[1] Bresee, F. W. (2007). Pastor's Pastor: Husband-wife team ministry," MINISTRY: International Journal for Pastors .10 (2), 12 - 24.

[2] Byler, J. (2008).The Art of Christian Leadership, Developing skills to lead God's people Lancaster, PA: Global Disciples

[3] Catherine, S.J. (2013). Letters to Pastor's Wives: When Seminary Ends and Ministry Begins. Phillipsbuerg, NJ: P \& R Publishers.

[4] Dai, L. \& Wang, L (2015). Review of Family Functions: The Relationship Doctors, Prescription for Better Communication in Your Marriage. Open Journal of Social Sciences 3 (1) 101 - 123.

[5] Dobson, J. K. (2012). Gospel Discipleship. Wheaton, IL: Crossway

[6] Fuller, B. (2010). Relate well, New York, West Bow Press

[7] Galen Peterson, g. (2013). In Defense of Marriage. Authors House: Liberty Drive

[8] Gauga, R. \& Christie, L. (2013). Clergy Stress and Depression. Retrieved on $22^{\text {nd }}$ February, 20019 from https//www.pdresources.org/uploads/Course/fib78

[9] Nandasaba, T.L. (2011). Determination of Effects of Stress to Pastors' Wives on Church Ministries Performance: A case of Bungoma.

[10] Schussler, E. (2007). In Memory of Her. New York: Crossroads

[11] Strauss, R. L. (2019)"Yes, My Lord- The Story of Abraham and Sarah" accessed 14 April 2019,http://bible.org/seriespage/2_yes_my_Lord_story_abraham_and_serah

[12] White, E. G (2007). Testimonies for the Church London: Stanborough,

[13] White, E. G (2005). Evangelism London: Stanborough,

[14] White, E. G. (2015).Adventist Home.Nashville, TN; Southern Publishing Association.

[15] Wimber, J. and Kevin S. (2007). Power Evangelism. San Francisco, CA: Harper and Row.

\section{AUTHOR'S BIOGRAPHY}

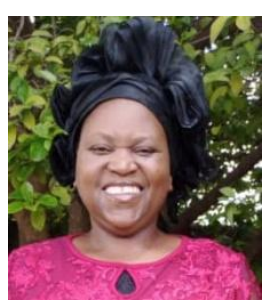

Linda Sibanda, is an an academician. She did a diploma in Primary Education at Gwanda Zintec College in Zimbabwe. Bachelor of Education in Religious Studies at Solusi University. Bachelor of Arts in Theology at Solusi University and Masters of Art in Religious Education at Solusi University. Currently she is pursuing a Doctor of Ministry Degree at Adventist University of Africa in Kenya. She taught at Solusi High School in Zimbabwe as well as Solusi University. She has also been an Adjunct lecturer at Rusangu University in Zambia. Part time lecturer at the University of Zambia. She is currently a full time lecturer at Eden University in Zambia. She is also a Pastor's Wife. They are currently saving under Midlands West Zambia Conference. She is a director of Women, Children and Health Ministries in Midlands West Zambia. Currently she is involved in Lecturing and Conference work in Midlands West Zambia Conference.

Citation: Linda Sibanda." The Role of a Pastor's Spouse in Church Growth: A Case Study of the Seventh Day Adventist Midlands Conference" International Journal of Humanities Social Sciences and Education (IJHSSE), vol 8,no.1, 2021, pp.44-54. doi:https://doi.org/ 10.20431/2349-0381.0801006.

Copyright: (C) 2021 Authors. This is an open-access article distributed under the terms of the Creative Commons Attribution License, which permits unrestricted use, distribution, and reproduction in any medium, provided the original author and source are credited. 